\title{
The Impact of New Zealand's Employment Contracts Act: A Response to Rod Lingard
}

\author{
Chris Eichbaum
}

A S New Zealand awaited the formation of its first government under the new mixed-member-proportional electoral system, nothing scemed more certain than that the Employment Contracts Act (ECA) would change. Such change could involve the repeal of the Act and its replacement with a statute more in keeping with International Labour Organisation (ILO) Conventions on collective bargaining and freedom of association, the introduction of a comprehensive minimum code, and greater encouragement for collective bargaining arrangements, including multi-employer contracts where appropriate. Alternatively, change could take a more incremental form, with the general scheme of the Act retained. A government of the centre-left would be likely to seek to repeal and replace the Act, while a centre-right coalition would probably entertain incremental reform.

In the event, a centre-right National-New Zealand First coalition has emerged, and, while only marginal changes are envisaged, both parties to the Coalition Agreement appear to have influenced the agenda for reform. Those commentators who have represented the ECA as an 'incomplete revolution' may be encouraged by references in the Coalition Agreement to the need to limit 'judicial activism'. On balance, it is not clear that there will be any substantial softening of the Act, notwithstanding the claims that will no doubt be made for some of the cosmetic changes by New Zealand First.

It is clear, however, that there is no suggestion of a return to a formal system of conciliation and arbitration, to monopoly rights of union representation, or to a system of bargaining dominated by multi-employer awards. But there is a concern to ensure that labour law promotes equitable outcomes, while ensuring the necessary degree of flexibility and responsiveness required for labour-market efficiency.

Any assessment of the impact of the ECA, and, by implication, the prospects for legislative reform, should explicitly articulate the preferences of stakeholders. Those who stand to gain from the present arrangements, which is to say those who have a vested interest in them, have an obligation to declare that interest if the debate over the merits of the ECA is to have the necessary integrity.

\section{Labour Market Failure}

With the passage of the Industrial Conciliation and Arbitration Act in 1894, New Zealand became a pioneer in labour legislation. It is salutary to reflect on the im- 
peratives that led the Liberal government of the time to sponsor the legislation. Evidence of 'sweating' - the exploitation of women (many of them outworkers) and child labour in the clothing industry - prompted widespread community concern. And the consequences of the 1890 Maritime Strike were of sufficient magnitude and concern to suggest that the orderly conduct of labour relations might appropriately be prosecuted by way of public policy. In short, labour legislation was justified by clear evidence of market failure, and informed by the dual imperatives of equity in outcomes and order in process. Moreover, in respect of the former imperative, market failure was most evident in what we would now refer to as the secondary labour market.

The evidence that Rod Lingard (1996) cites in his recent note in Agendasurvey results on the preferences of employers and employees, and on the outcomes of bargaining under the ECA - should not obscure the fundamental issue that separates supporters and opponents of radical labour-market liberalisation. That issue goes to the heart of the nature of the labour market. Those of a libertarian persuasion argue that 'It is a common delusion to treat people's choice to sell their labour as fundamentally different from other economic choices they might take' (Garvey, 1994:11). In stark contrast, others have suggested that

The heart of the problem is that the labour market cannot be visualised as a market like any other, with unions blocking prices from doing their proper job of equalising the supply and the demand for labour. Human beings are not tradeable commodities. As . . . Robert Solow argues, the theoretical categories that might apply to analysing trade in chocolate bars, fish or computers cannot be extended to labour because we have to confront the issues of fairness, morale and human motivation that permeate human action. (Hutton, 1995:98-9)

Much empirical evidence exists relating to the impact of the ECA. But identifying cause and effect, particularly with regard to the macroeconomic impacts of the ECA, is problematic, particularly in view of the absence of a counter-factual. Moreover, the impact of the ECA is not easily separated from other policy changes. Legislating for an effective reduction in union influence, increased individual contracting at the lower end of the market, and a tightening of benefit eligibility and reductions in entitlements will tend to result in the expected shifts in supply and price. That has demonstrably been the case in New Zealand, and the ECA has been only part of the story.

\section{Bargaining Outcomes}

Lingard's use of evidence is at times selective, and some of his conclusions appear not to be supported by any evidence at all.

Lingard cites approvingly research undertaken by the New Zealand Institute of Economic Research (NZIER) on the impact of the ECA, but his reporting of the research is somewhat selective. Of the employers surveyed by the NZIER, 42.6 per 
cent indicated that they had reduced overtime rates, and 38.8 per cent had reduced other allowances and/or penal rates. Some 40 per cent of employers surveyed reported no change in ordinary-time wage rates in the period from the passage of the ECA to December 1995 (Savage, 1996).

There is absolutely no evidence to support Lingard's assertion that those covered under collective contracts have made relatively smaller 'gains' than those employed on individual contracts. Statistics New Zealand simply has no way of identifying the type of contract coverage in computing wage/income changes. What we do know is that there is evidence of inequality in bargaining outcomes: in the past year, 46 per cent of wage rates have not changed, but a quarter have increased by more than 3 per cent.

We also have evidence on the pattern of collective-contract coverage by size of enterprise and by sector. Approximately 23 per cent of workers are covered by collective employment contracts, but only 16 per cent of those workers are under contracts covering fewer than 100 workers. This creates a less than 3 per cent chance that a worker in a small (under 100) workplace will be covered by a collective employment contract; yet 75 per cent of workers are in that situation (NZCTU, 1996). A recent review of the data on contract coverage concludes with the observation that 'the right to collective representation in setting conditions of employment has nothing to do with democracy or free choice. It is simply a factor of scale of employment' (NZCTU, 1996:63).

What about the much vaunted productivity dividend? The NZIER reports that 'aggregate data implies that productivity performance in recent years has been below average' (1996:11), and the OECD has noted that, 'there is not much evidence at the macroeconomic level ... that the ECA has led to increased flexibility and improvements in productivity' (cited in NZCTU, 1996:12).

Lingard fails to report evidence of the impact of the ECA on a labour market that is segmented by gender. In May 1996, Douglas Myers, Chairman of the New Zealand Business Roundtable, suggested that the ECA had been good for women, and argued that 'Women's interests rarely got a fair hearing in male-dominated trade unions committed to a 40 hour week; the extra flexibility in working hours and growth in part-time jobs have been of great advantage for them' (Myers, 1996). In fact, research on bargaining outcomes suggests that, under the ECA,

women are less likely than men to be employed on contracts that contain penalty rates of pay. Women are disadvantaged in that the sectors in which they are most commonly employed are exactly those sectors where penalty rates, for working at weekends and other hours that have traditionally been deemed sufficiently anti-social to attract a premium rate of pay, have been eliminated. (Hammond \& Harbridge, 1995:372)

The same authors suggested, prior to the introduction of the Australian government's Workplace Relations Bill, that decentralisation of bargaining in Australian 
workplaces risked a worsening of the 'structural inequalities of industry segmentation' (Hammond \& Harbridge, 1995:374).

\section{Employee Representation}

Lingard notes that there has been a decline in levels of union representation, and offers the observation that this is part of a 'steady and relentless' (p. 495) and 'continuing decline' (p. 496). That there has been a decline is without question. That the ECA has largely contributed to the decline is likewise not in dispute. But what it is about the ECA that has prompted this decline is an issue on which there is a greater range of views than Lingard's assessment might suggest. And Lingard's commentary, while selective, attests to this by suggesting, variously, that the decline is a function of a 'free and contestable labour market', and that a decline in unionisation in the services sector may have something to do with the fact that, for unions, this is a 'difficult' sector in which to organise (p. 496).

The above observations on the pattern of collective bargaining are clearly apposite in this regard. There is simply no evidence to support the suggestion that unions are losing market share: quite the opposite. A recent review of the pattern of representation (for 3,216 contracts covering 403,000 employees) suggests that

Non-traditional unions (in-house unions or bargaining agents) have not developed as an important force... They continue to represent just 2 per cent of employees in our sample. Traditional unions have maintained their market share representing some 89 per cent of employees. (Harbridge, Crawford \& Kiely, 1996:10)

\section{The ECA and ILO Conventions}

The ECA fails to meet the tests of the relevant ILO Conventions. Reviewing the Final Report of the ILO Committee on Freedom of Association, which undertook a Direct Contact Mission to examine the impact of the ECA, Haworth and Hughes (1995:154) report that

the ILO continues to entertain grave concerns about the operation of the ECA on two counts. First, the status of individual bargaining given by the ECA is in direct contradiction to ILO principles of collective bargaining and, by extension, to the parallel principles of tripartism. In the discourse of the ILO, this criticism remains a fundamental issue putting the ECA at odds with ILO practice. In a host of contexts, not only that of Convention 98, the ILO has established precedence for collective bargaining in labour relations and the ECA contradicts this precedence.

It is interesting to note that Australia's Workplace Relations Bill may be inconsistent with ILO Conventions to which the Australian government is a signatory. 


\section{Conclusion}

Advocates of the kinds of neoclassical policy prescriptions of which the ECA is an exemplar typically justify the need for radical liberalisation, in part at least, on the grounds that formal systems of conciliation and arbitration militated against the necessary degree of flexibility in process and outcomes. Lingard's conclusion paints a picture of a set of institutional arrangements in Australia, by implication under the ALP-ACTU Accord, corrupted by vested interests, characterised by statist control, creating distortions, and pricing individuals out of the labour market. This commentary is not the place to contest Lingard's jaundiced assessment of those arrangements. Suffice it to say that the recent course of Australian public policy and the emerging debate over the future policy trajectory deserves more than the facile treatment that Lingard offers.

Australia has a choice. The relevant issues do not revolve so much around whether jobs can be produced by the kinds of supply-side reforms that the ECA and adjustments to welfare arrangements permit. Rather, they revolve around the kinds of jobs that will be generated; whether or not international competitiveness is a function solely of the relative price of labour; and the contribution made by the quality of a nation's human capital.

\section{References}

Garvey, G. (1994), 'Why Labour Is Not Different', Agenda 1(1): 5-12.

Hammond, S. \& R. Harbridge (1995), 'Women and Enterprise Bargaining: The New Zealand Experience of Labour Market Deregulation', The Journal of Industrial Relations 37(3): 359-76.

Harbridge, R., A. Crawford \& P. Kiely (1996), Employment Contracts: Bargaining Trends and Employment Law Update 1995/96, Industrial Relations Centre, Victoria University of Wellington, Wellington.

Haworth, N. \& S. Hughes (1995), 'Under Scrutiny: The ECA, the ILO and the NZCTU Complaint 1993-1995, New Zealand Joumal of Industrial Relations 20(2): 143-61.

Hutton, W. (1995), The State We're In, Jonathan Cape, London.

Lingard, R. (1996), 'The Impact of New Zealand's Employment Contracts Act: A Preliminary Assessment', Agenda 3(4): 493-8.

Myers, D. (1996), 'Why Not Full Employment by 2000 ', paper presented at the 'Moving Forward' conference on the Employment Contracts Act, Auckland (15 May).

New Zealand Council of Trade Unions (NZCTU) (1996), Post-election Prionities, Wellington.

Savage, J. (1996), 'What Do We Know About the Economic Impacts of the ECA?', paper presented at the 'Moving Forward' conference on the Employment Contracts Act, Auckland (15 May). 